\title{
Amasya kent örneğinde rekreasyon alanları bilgi sistemi oluşturulmasına yönelik bir çalışma
}

\section{An Investigation on creating recreation area information system at Amasya city sample}

\author{
Banu Çiçek KURDOĞLU ${ }^{1}$, Sultan Sevinç KURT KONAKOĞLU² \\ ${ }^{1}$ Karadeniz Teknik Üniversitesi, Orman Fakültesi, Peyzaj Mimarlığı Bölümü, Trabzon, Türkiye \\ ${ }^{2}$ Amasya Üniversitesi, Mimarlık Fakültesi, Kentsel Tasarım ve Peyzaj Mimarlığı Bölümü, Amasya, Türkiye
}

\section{Eser Bilgisi / Article Info}

Araştırma makalesi / Research article

DOI: $10.17474 /$ artvinofd.273783

Sorumlu yazar / Corresponding author

Banu Çiçek KURDOĞLU

e-mail:

banukurdoglu@windowslive.com

ORCID: 0000-0003-4683-8581

Geliş tarihi / Received

06.12.2016

Düzeltme tarihi / Received in revised form

02.11.2017

Elektronik erișim / Online available

20.04.2018

\section{Anahtar kelimeler:}

Rekreasyon

Rekreatif etkinlik

Rekreasyon Alanı Bilgi Sistemi

Yeşilırmak vadisi

\section{Keywords:}

Recreation

Recreative activity

Recreation Area Information System

Yeşilırmak Valley

\begin{abstract}
Özet
Hızlı ve düzensiz kentleşme hareketleri, günümüz kentlerini fiziksel, sosyal, biyolojik ve hijyenik yönden sorunların yer aldığı yaşam alanlarına dönüştürmektedir. Bu durum, doğal çevrede yaşayan canlıların yaşamlarını olumsuz yönde etkilemektedir. Doğal yapının tahrip edilmesinden dolayı kent insanı serbest zamanını geçirebileceği rekreasyon alanlarına gereksinim duymaktadır. Kent parkları, çay bahçeleri, mesire yerleri, gezi-dinlenme alanları, yürüyüş yolları kent içi veya kırsal alanlarda en çok tercih edilen rekreasyon alanlarııın başında gelmektedir. Çalışma alanı olarak doğal, tarihi, turistik özelliklere, doğal bir koridor olan Yeşilırmak Nehri ve Vadisi'ne sahip Amasya kenti seçilmiştir. Bu çalışmada, Amasya kent içi ve yakın çevresindeki rekreasyon alanları ile bu alanlarda gerçekleştirilen etkinlikler belirlenmiştir. Alana ait veriler, Macellan marka el tipi GPS yardımıyla rekreasyon alanlarından alınan koordinatlar CBS ortamı ve Arcview 10.1 programında sayısal haritalar ile uydu görüntüsüne işlenerek rekreasyon bilgi sistemi veri tabanı oluşturulmuştur. Kent halkı ile yapılan görüşme ve değerlendirmelere göre; Amasya kent içinde 10 adet, kent çevresinde 7 adet rekreasyon alanı tespit edilmiştir.
\end{abstract}

\begin{abstract}
Rapid and irregular urbanization movements turn cities into places with physical, social, biological, and hygienic problems. This situation affects negatively the lives of living creatures in the natural environment. Destruction of natural texture increases the need for people living in cities for recreation areas where they can spend their spare time. Urban parks, tea cafes, excursion spots, resting areas, walkways are the most preferred recreation areas in urban areas or in rural areas. The city of Amasya was selected for this study because of natural, historical, and touristic characteristics of YeÅ ̈̈ilÄtrmak River and Valley natural corridor. In this study, recreation areas both in Amasya and around it, and recreative activities in this place were determined. Information system database was created in GIS environment by ArcView 10.1 program; using coordinates obtained with Magellan brand handheld GPS from recreation areas to process maps and satellite images. According to interviews and evaluations made with the people of the city, results showed that there were 10 recreation areas in city and 7 around the city.
\end{abstract}

\section{GiRiş}

Günümüz kentlerinde görülen hızlı ve düzensiz kentleşme hareketleri fiziksel, sosyal, biyolojik ve hijyenik yönden sorunları da beraberinde getirmektedir. Bu durum doğal çevre üzerinde yaşayan canlıları olumsuz etkilemektedir. Dolayısıyla doğal yapının tahrip edildiği kentlerdeki insanlar, açık-yeşil alanlardan uzaklaşmakta olup fiziksel, zihinsel ve psikolojik açıdan zarar görmektedir (Kurt 2013, Kurdoğlu ve ark. 2014). Özellikle kent ve çevresinde görülen olumsuz sonuçlar, insan-çevre ilişkisinin sağlıklı biçimde yürümesini sağlayacak rekreasyon alanlarına olan gereksinimi arttırmaktadır (Yılmaz 2006, Akten ve Akten 2011, Akyüz ve ark. 2014).
Albay (2006)'a göre; rekreasyon çağımız toplumlarının ayrılmaz bir parçası olmuştur (Karahan ve Orhan 2009, URL-1 2016). Rekreasyon Latince 're-tekrar' ve 'createyaratma' kelimelerinden türemiş olup yenilenme, yeniden yaratılma, yapılanma ya da kazanılma anlamına gelmektedir (Akten 2003). Türkçe karşılığı ise boş zamanları değerlendirme olarak kullanılmaktadır. Bu durum bireylerin günlük yaşamın sıkıcı ve monoton geçen çalışmanın etkisinden kurtulmak için boş zamanlarında gönüllü olarak yaptıkları dinlendirici ve eğlendirici etkinlikler anlamına gelmektedir. Insanlar boş zamanlarında; uzaklaşmak, dinlenmek, hava değişimi, gezme-görme, sağlık, beraber olma, heyecan duyma, farklı yaşantılar elde etme gibi pek çok amaçla, kent içinde 
veya kırsal alanlarda etkinliklere katılmaktadırlar (Karaküçük 1999, Karahan ve Orhan 2009).

Kent içinde ya da kırsal rekreasyon alanlarında; yürüme, koşma, oturma, yemek-yeme, sohbet etme, rafting, kayıkla gezinti, su kayağı yapma, yüzme, balık tutma, dağcılık, hiking, bisiklet ve motosikletle gezinti, çim kayağı, atla gezinti, yayla şenliklerine katılma, kamp yapma, piknik yapma, fotoğraf çekme, avcılık, manzara seyretme gerçekleştirilen başlıca rekreatif etkinliklerdir.

Bilişim çağında yaşamamızın sonucu olarak, bilgi sistemlerinin kullanımı her alanda giderek yaygınlaşmakta ve teknoloji performansı katlanarak artmaktadır. Sahip olunan bilgiyi aktif ve güncel kullanmakta son derece önemli olduğundan bilgilerin bir sistem kapsamında toplanıp işlenmesi gerekmektedir. Mevcut bilgilerin bir araya getirilip saklanması, analiz edilmesi ve kullanıcı ihtiyacına göre sunulması "bilgi sistemi" olarak adlandırılmaktadır. Bilgi sistemlerinin temel fonksiyonu karar verme işlemini kolaylaştırarak bu süreci kısaltmaktır. Coğrafi Bilgi Sistemleri'nin bilgi sistemlerinden farkı; sistemin değişik nesnelere ait öznitelik bilgilerine ilave olarak konum bilgilerini de içermesidir (Sağlam ve ark. 2004, Gülbay 2007, Kurt ve Kurdoğlu 2016). Bir bilgi teknolojisi olan Coğrafi Bilgi Sistemleri (CBS), mekana bağlı değerlendirme yapabilmeyi sağlayan bir araçtır. CBS sayesinde bilgi akışı hızlanmakta, daha verimli üretim ve envanter yönetimi sağlanmakta, iş verimliliği artmakta, etkili ve doğru analizler yapılmakta, veri güncelleme kolaylığı sağlanmakta, iş gücünü arttırıp zaman kaybı önlenmektedir (Aranoff 1989, İlhan 1999, Yomralıoğlu 2002, Sağlam ve ark. 2004). Çalışmada CBS sağladığı sorgulama sistemiyle talep edilen bilgiye kolaylıkla erişim imkanı tanıdığı için kullanılmıştır.

$\mathrm{Bu}$ çalışmanın amacı, ülkemizde yaygın olarak kullanılmayan rekreasyon alanları bilgi sisteminin oluşturulmasına yönelik bir altlık oluşturmaktır. Kente ziyarete gelen bir turist kentte yer alan rekreasyon alanlarını ve rekreasyonel olanakları bu sistem sayesinde kolaylıkla öğrenebilecektir. Çalışma sonucunda Amasya kent merkezi ve yakın çevresinde yer alan mevcut rekreasyon alanlarının konumları, büyüklükleri, kent merkezine olan uzaklıkları, alanların sunduğu olanaklar ve alanda yapılan etkinliklere ait bilgilerin yer aldığı bir veri tabanı CBS ortamında oluşturulmuştur. Bu veri tabanı turistler için en uygun rota belirleme, farklı alanları karşılaştırma gibi amaçlar doğrultusunda analiz edilmeye/sorgulamaya olanak tanımaktadır. Ayrıca, alanlara ait bilgilerdeki değişiklikler veri tabanında güncellenebilmekte ve kent için yapılan ya da yapılacak olan başka bilgi sistemleri (kent bilgi sistemi, ulaşım bilgi sistemi, turizm bilgi sistemi vb.) ile entegre olabilecek altyapıya sahiptir.

\section{MATERYAL ve YÖNTEM}

Çalışma alanı olarak; geleneksel Osmanlı Evi örneklerinin Yeşilırmak Nehri ve Vadisi boyunca yer aldığı, tarihi kent dokusu, doğal ve kültürel değerlerinin yoğun olarak bulunduğu Amasya ili seçilmiştir. Amasya kenti (Şekil 1) eski hüviyetini koruyabilen nadir bir ilimizdir. Kentin 7500 yıllık tarihi geçmişe ev sahipliği yapmasından dolayı kent açık hava müzesi özelliğini taşımakta olup Kültür ve Turizm Bakanlığı'nın belirlediği marka kent kapsamındaki 15 ilden birisidir. Kent tarihi, kültürel, doğal güzellikleri, turistik yerleri, termal tesisleri ve endemik türleri ile zengin turizm potansiyeline sahiptir. Fiziksel büyümeye pek müsait olmayan coğrafi yapısından, sanayinin pek fazla olmaması ve göç almamasından, kültürel ve tarihi zenginlikten, görülmeye değer doğal güzellik ve manzaralarından dolayı kentte daha çok kültür ve inanç turizmi yapılmaktadır (Anonim 2010, Kurt 2013, Kurdoğlu ve ark. 2014, URL-2-3 2016, Kurdoğlu ve Kurt 2017).

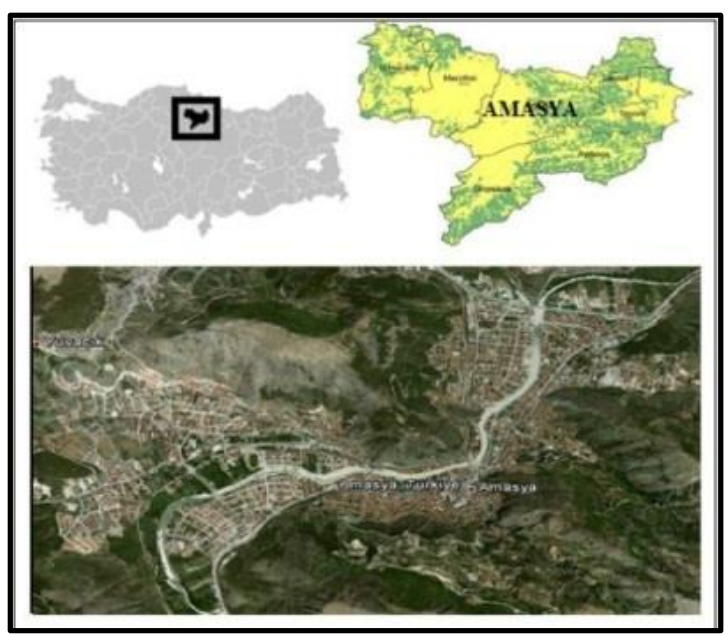

Şekil 1. Çalışma alanı (Google Earth, 2013; Kurt, 2013) 
Çalışmanın yöntemi; veri toplama, gözlem, inceleme ve değerlendirmeden oluşmaktadır. Arazi çalışması kapsamında kentteki rekreasyon alanlarından fotoğraf çekilmiş olup günün farklı saatlerinde yerinde gözlem yapılmıştır. Macellan marka el tipi GPS yardımıyla rekreasyon alanlarından alınan koordinatlar, rekreasyon alanlarının isimleri, kent merkezine olan uzaklıkları, alana ulaşım şekli ve bu alanlarda gerçekleştirilen etkinliklere ait bilgiler CBS ortamına girilerek Amasya kenti için rekreasyon alanları bilgi sistemi veri tabanı oluşturulmuştur. CBS ortamında rekreasyon alanları bilgi sistemi veri tabanı oluşturulurken aşağıdaki öznitelik verileri girilmiştir (Şekil 2):

- Fid; girilen verilerin layer'a göre sıralaması $(1,2,3, \ldots)$

- Shape; girilen verinin biçimi (Point, Line, Poligon)

- Name; girilen her bir rekreasyon alanının ismi

- Kente Mesafe; girilen her bir rekreasyon alanının konumu ve kent merkezine uzaklığı

- Etkinlik; girilen her bir rekreasyon alanında gerçekleştirilen aktiviteler (yürüme, yeme-içme, fotoğraf çekme, ....)

- Ulaşım; girilen her bir rekreasyon alanına ulaşım şekli (yürüme, otobüs, minibüs, ...)

- Büyüklük; girilen her bir rekreasyon alanının m2 olarak kapladığı alan
- Tür; girilen her bir alanın sınıflandırmasına göre türü (çay bahçesi, park, kale, piknik alanı, orman, ...)

Her bir rekreasyon alanının öznitelik verileri katmanlar dahilinde Arcview 10.1 programında sayısal haritalar ile uydu görüntüsüne işlendikten sonra kent içi ve çevresinde yer alan rekreasyon alanlarını gösteren nihai harita oluşturulmuştur (Şekil 2).

Veri girişi tamamlandıktan sonra şu analizler yapılmıştır:

- Rekreasyon alanlarının kent merkezine yakınlık durumu,

- Rekreasyon alanlarında gerçekleşen etkinliklerin durumu,

- Rekreasyon alanlarının büyüklüğü ile alanlarda gerçekleşen etkinliklerin uyumu,

- Rekreasyon alanlarına ulaşım durumu,

- Rekreasyon alanları için en uygun güzergâh seçimi.

Kent halkı ile yapılan görüşme, yerinde yapılan gözlem ve değerlendirmelere göre; Amasya kent insanının serbest zamanlarını Yeşilırmak Nehri boyunca düzenlenmiş gezi yolunda, kent içi ve çevresinde yer alan çay bahçeleri ile mesire alanlarında geçirdiği görülmektedir.
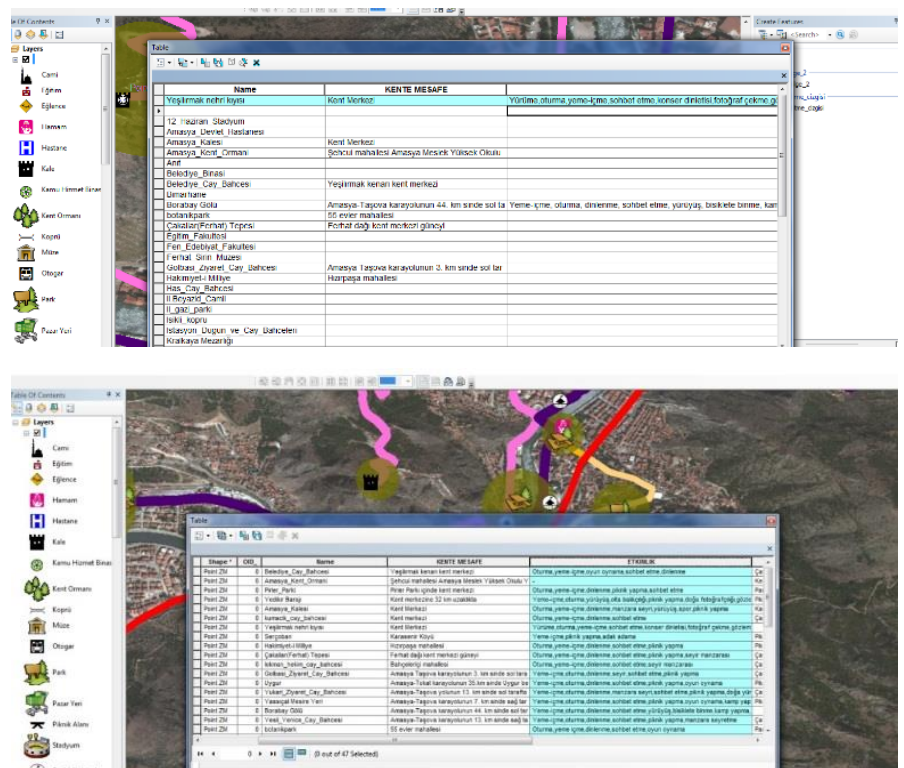

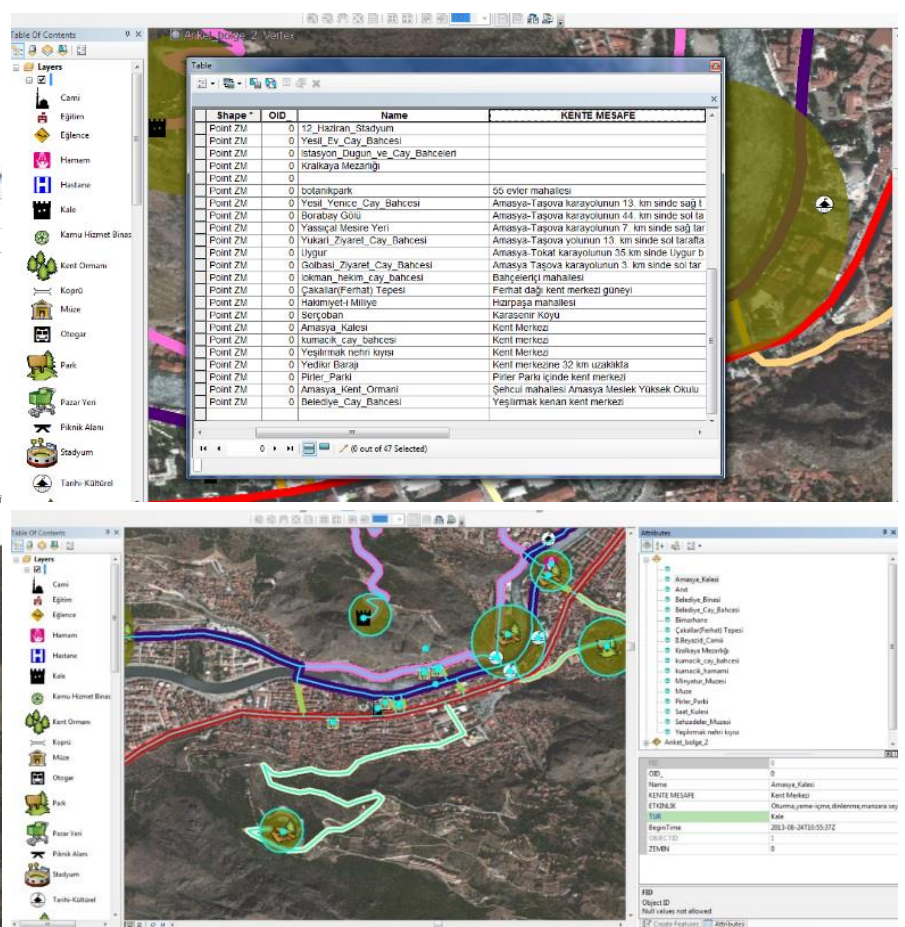

Şekil 2. CBS veri girişi ve rekreasyon alanları bilgi sistemi oluşturulurken izlenen adımlar 


\section{BULGULAR}

\section{Kent İçindeki Rekreasyonel Olanaklar}

\section{Belediye parkı çay bahçesi}

il merkezinde Yeşilırmak'ın kenarında $2.346 .304 \mathrm{~m} 2$ büyüklüğündeki alanda yer almaktadır. Alan içerisinde açık ve kapalı yeme-içme mekânları, çok amaçlı oyun parkı bulunmaktadır. Bu durum dinlenme, oturma, sohbet etme, yeme-içme, oyun oynama, müzik dinletisi, manzara seyretme etkinliklerine olanak sağlamaktadır (Şekil 3, Şekil 14).

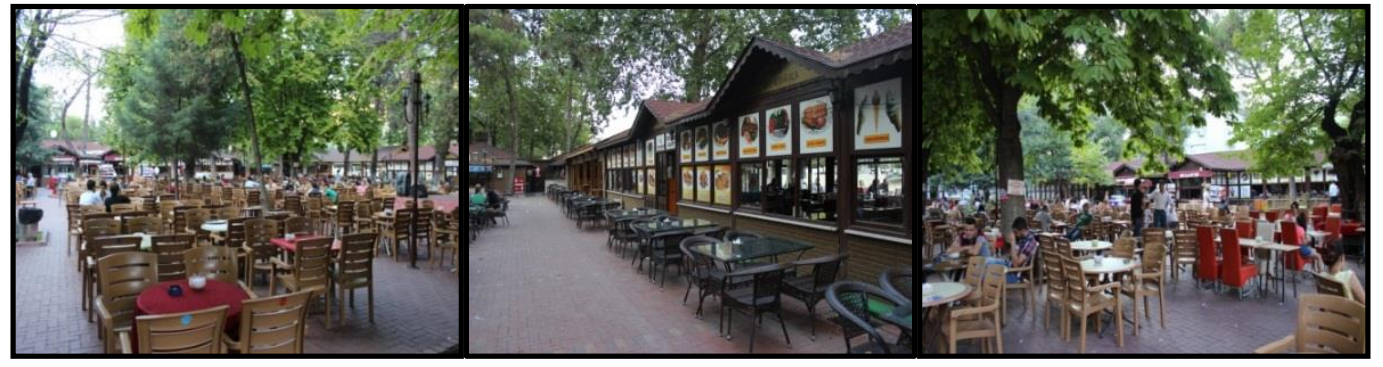

Şekil 3. Belediye Parkı çay bahçesinden görünümler (Kurt 2013)

\section{Pirler parkı çay bahçesi}

il merkezinde $652.100 \mathrm{~m}^{2}$ lik alan içerisinde yeme-içme alanları ile piknik alanı bulunmaktadır (URL-4 2013, URL-5
2016). Alanda dinlenme, oturma, yeme-içme, sohbet etme, piknik yapma etkinlikleri gerçekleştirilmektedir (Şekil 4, Şekil 14).

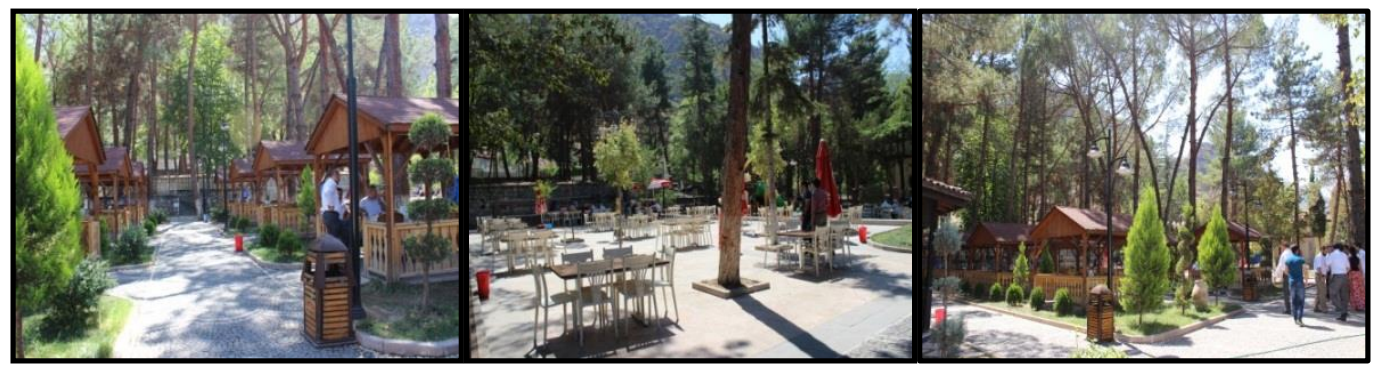

Şekil 4. Pirler Parkı çay bahçesinden görünümler (Kurt 2013)

\section{Kumacık parkı çay bahçesi}

il merkezinde $479.161 \mathrm{~m}^{2}$ büyüklüğünde alanda olup içerisinde yeme-içme alanları bulunmaktadır. Alanda dinlenme, oturma, yeme-içme, sohbet etme etkinlikleri gerçekleştirilmektedir (Şekil 5, Şekil 14).

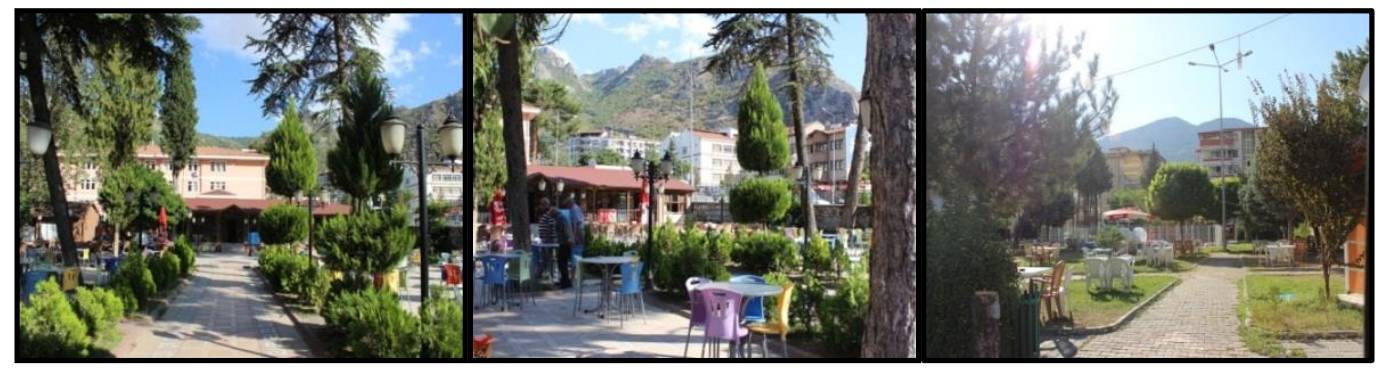

Şekil 5. Kumacık Parkı çay bahçesinden görünümler (Kurt 2013)

\section{Milli hâkimiyet parkı}

II merkezinde Hızırpaşa Mahallesinde $23.849 .679 \mathrm{~m}^{2}$ lik alanda yer almaktadır. Parkta, piknik alanları ile yeşil alanlar bulunmaktadır. Bu durum alanda dinlenme, oturma, yeme-içme, sohbet etme, piknik yapma, spor yapma etkinliklerinin yapılmasına imkân sağlamaktadır (Şekil 6, Şekil 14). 


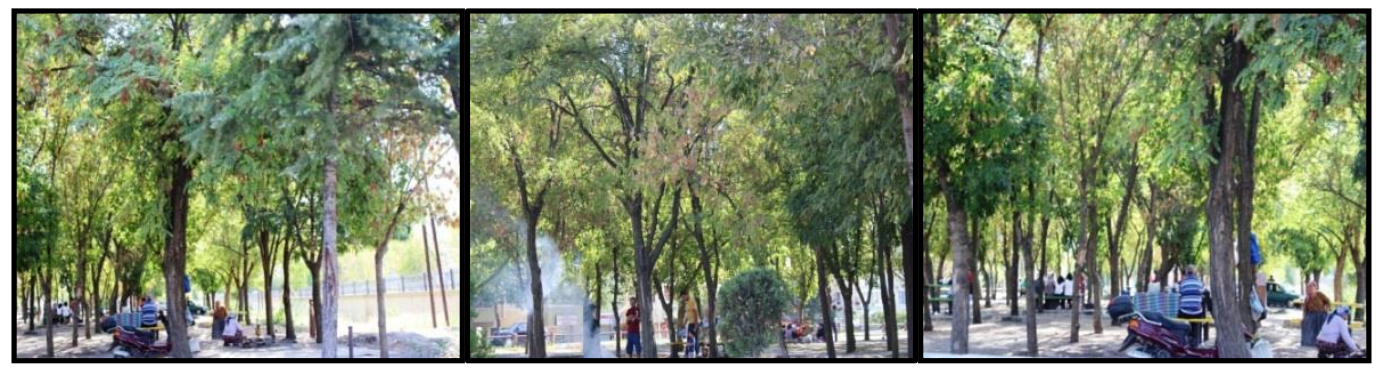

Şekil 6. Milli Hakimiyet Parkı'ndan görünümler (Kurt 2013)

\section{Lokman Hekim çay bahçesi}

il merkezinde Bahçeleriçi Mahallesinde ve şehir merkezinin kuşbakışı izlenebildiği yükseklikte 1.485.146 $\mathrm{m}^{2}$ büyüklüğündeki alanda yer almaktadır. Alanda seyir terasları, açık ve kapalı yeme-içme mekânları ile yeşil alanlar bulunmaktadır. Alanda dinlenme, oturma, yemeiçme, sohbet etme, manzara seyretme, fotoğraf çekme etkinlikleri gerçekleştirilmektedir (Şekil 7, Şekil 14).

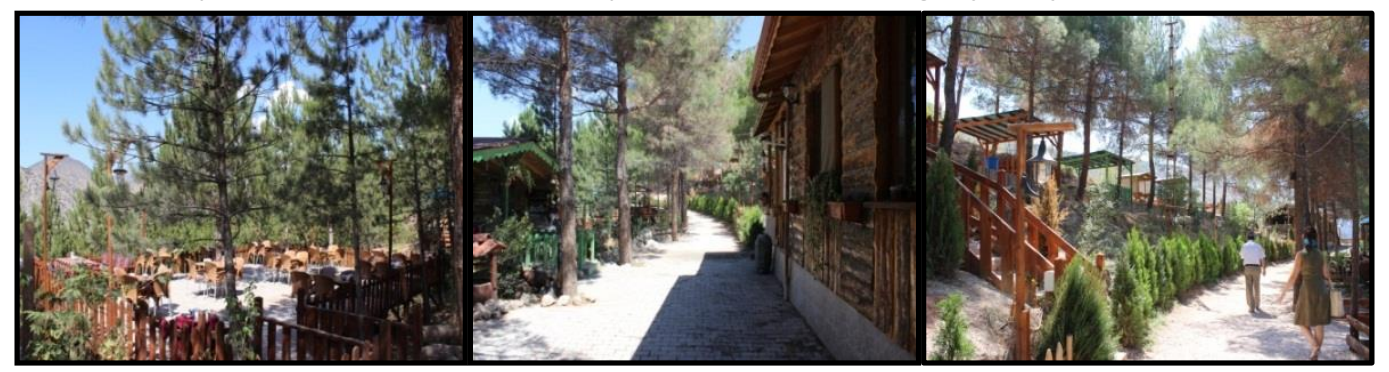

Şekil 7. Lokman Hekim çay bahçesinden görünümler (Kurt 2013)

\section{Botanik park}

II merkezi 55 Evler Mahallesi'nde $7.231 .355 \mathrm{~m}^{2}$ lik alanda yer almaktadır. Alan içerisinde açık ve kapalı yeme-içme mekânları, çocuk oyun alanı, süs havuzları ile yeşil alanlar bulunmaktadır. Burada yer alan mekânlar oturma, dinlenme, sohbet etme, yeme-içme, oyun oynama etkinliklerine olanak sağlamaktadır (Şekil 8, Şekil 14).

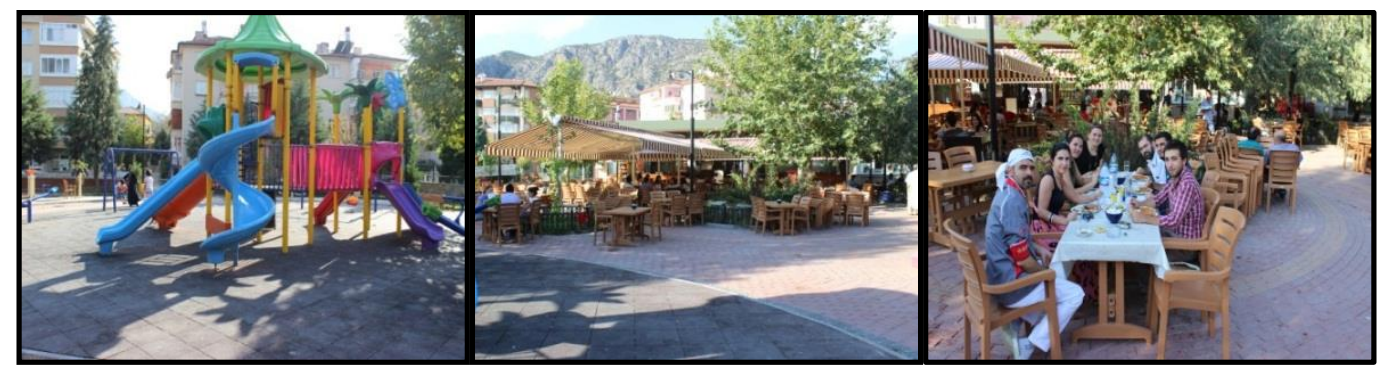

Şekil 8. Botanik Park'tan görünümler (Kurt 2013)

\section{Ferhat tepesi (Çakallar seyir terası)}

Kent merkezinin güneyinde kentten 250 metre yükseklikte $5.762 .838 \mathrm{~m}^{2}$ alanda yer almaktadır. Alan içerisinde yeme-içme alanları, piknik alanı, kent merkezi ile vadinin kuşbakışı izlenebildiği şehir terası bulunmaktadır (URL-4 2013, URL-2 2016, URL-5 2016). Alan oturma, dinlenme, yeme-içme, sohbet etme, manzara seyretme, fotoğraf çekme, piknik yapma, yürüme etkinliklerine elverişlidir (Şekil 9, Şekil 14). 


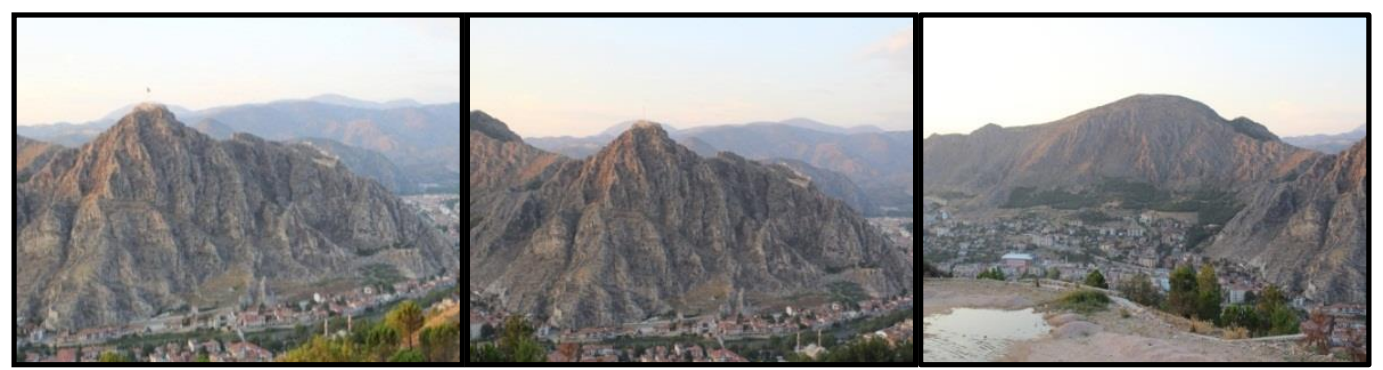

Şekil 9. Ferhat Tepesi'nden kentin görünümü (Kurt 2013)

\section{Yeşilırmak Nehri kıyısı}

Kent merkezinden geçen Yeşilırmak Nehri boyunca düzenlenmiş rekreasyon alanlarında kullanıcılar yürüme, oturma, yeme-içme, sohbet etme, dinlenme, konser dinletisi, fotoğraf çekme, manzara seyretme, gözlem yapma, balık tutma etkinliklerinde bulunmaktadır. Alan
3.215.256 $\mathrm{m}^{2}$ olup içerisinde oturma birimleri, seyir cumbaları, amfi tiyatro, Ferhat ile Şirin heykeli, ünlü coğrafyacı Strabon heykeli, Amasya'da valilik yapan şehzadelere ait heykeller, çeşmeler yer almaktadır (Şekil 10-11, Şekil 14). Alan yerli ve yabancı turistlerin ilgisini çekmekte ve her mevsim yoğun olarak kullanılmaktadır.

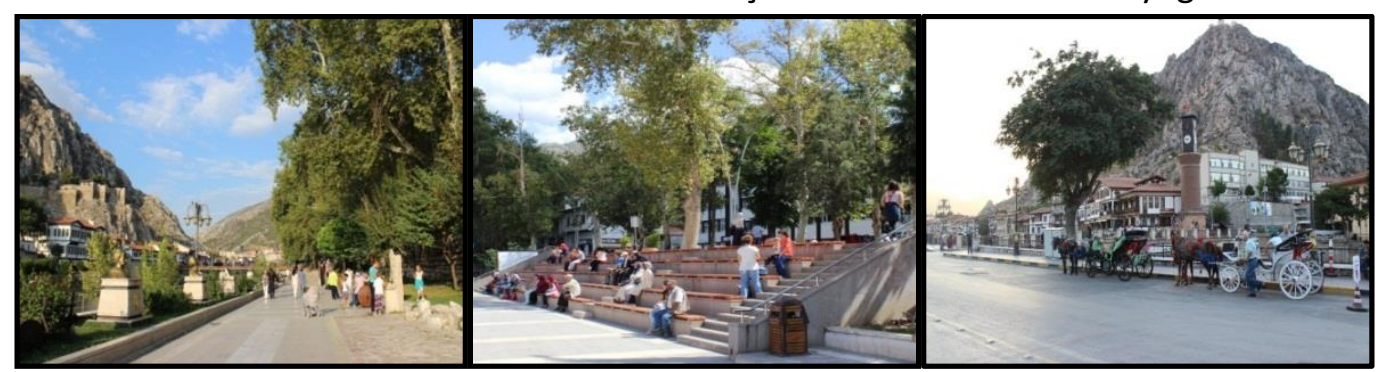

Şekil 10. Yeşilırmak Nehri kıyısından görünümler (Kurt 2013)

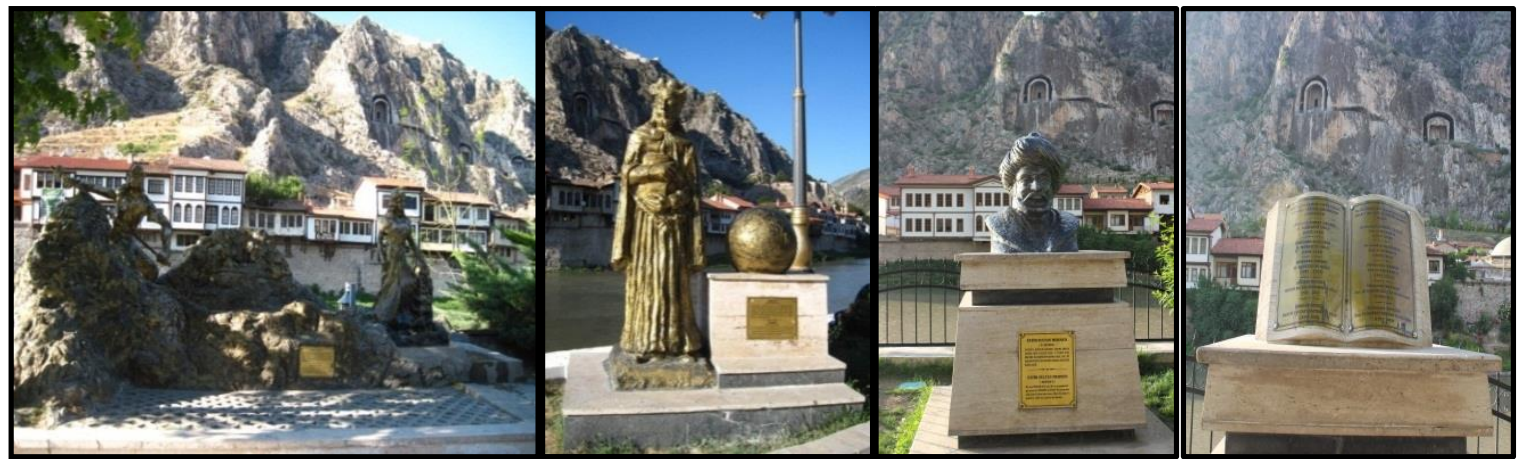

Şekil 11. Yeşilırmak Nehri kenarında yer alan Ferhat ile Şirin heykeli, ünlü coğrafyacı Strabon heykeli, Amasya'da valilik yapan şehzadelere ait heykeller (Kurt 2013)

\section{Amasya kalesi}

Alan il merkezinde $1.539 .281 \mathrm{~m}^{2}$ büyüklüğünde yer almaktadır. Alanın doğal güzelliği ve tarihi değeri vardır.
Alanda yürüyüş, manzara seyretme, spor ve piknik yapmak mümkündür (Şekil 12, Şekil 14).

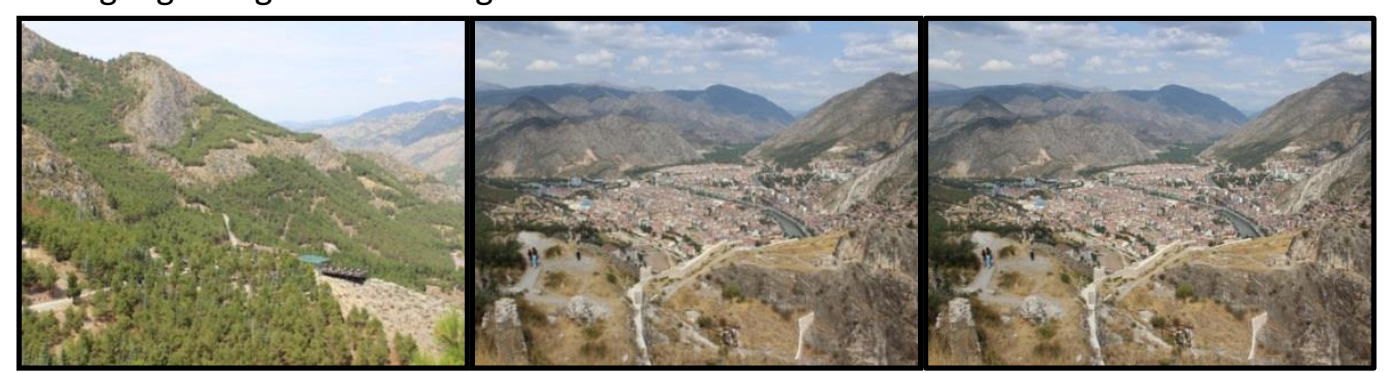

Şekil 12. Amasya Kalesi'nden görünümler (Kurt 2013) 


\section{Amasya kent ormanı (Çamlık piknik alanı)}

II merkezi Şeyhcui Mahallesi'nde Amasya Üniversitesi Meslek Yüksek Okulu bitişiğinde bulunmaktadır. 2012 yılına kadar kent ormanında dinlenme, spor, yürüyüş, manzara seyri ve piknik yapmak mümkündü ancak
'Amasya Çevre Yolu' projesinden dolayı tahrip edilmekte ve geçici bir süre için rekreasyona kapatılmıştır. Proje bittiğinde tekrar rekreasyon amaçlı kullanıma açılacaktır (Şekil 13, Şekil 14).

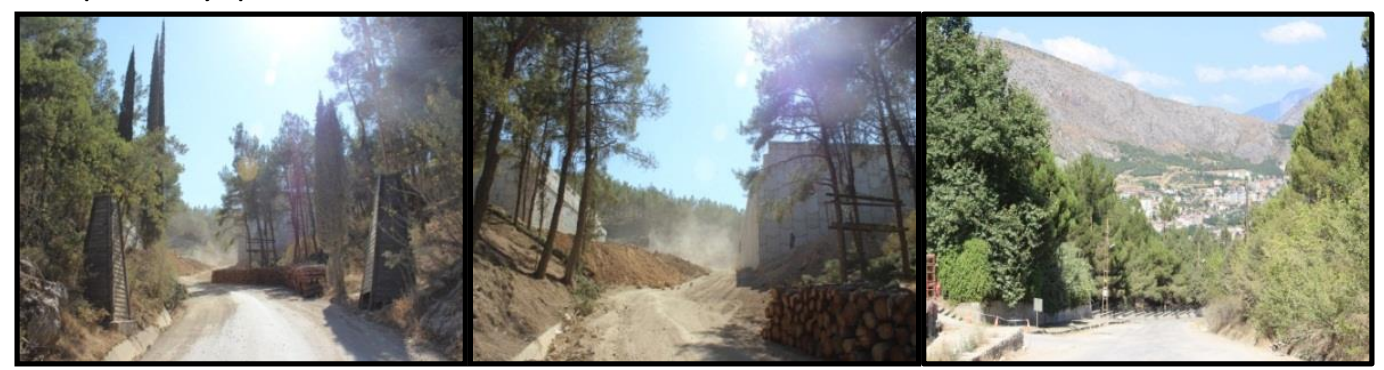

Şekil 13. Amasya Kent Ormanı'ndan görünümler (Kurt 2013)

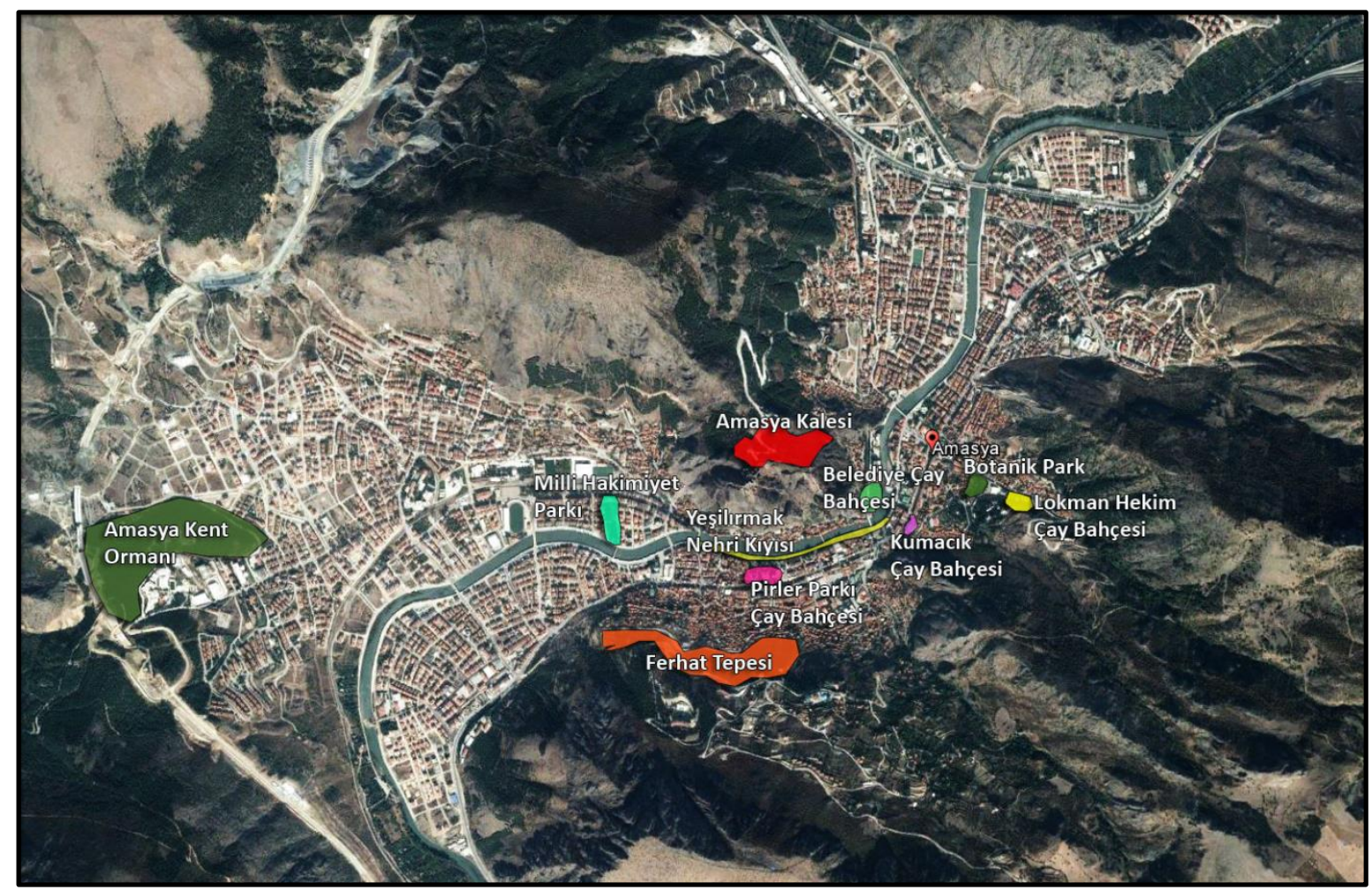

Şekil 14. Amasya kent içindeki rekreasyon alanlarının yerini gösteren harita

\section{Kent Çevresindeki (Kırsal Alanlarda) Rekreasyonel Olanaklar}

\section{Yeşil Yenice kasabası piknik alanı}

Amasya-Taşova karayolunun 13 . km.'sinden sağa ayrılarak ulaşılmaktadır. Alan içerisinde 800 yıllık anıtsal çınar ağacı, süs havuzu, yeme-içme alanı, piknik alanı ve otopark bulunmaktadır (URL-4 2013, URL-5 2016). Kent merkezine $13 \mathrm{~km}$. uzaklıktadır. Alan dinlenme, oturma, yeme-içme, sohbet etme, spor yapma, yürüyüş, manzara seyretme, piknik yapma etkinliklerine olanaklıdır (Şekil 15, Şekil 22). 


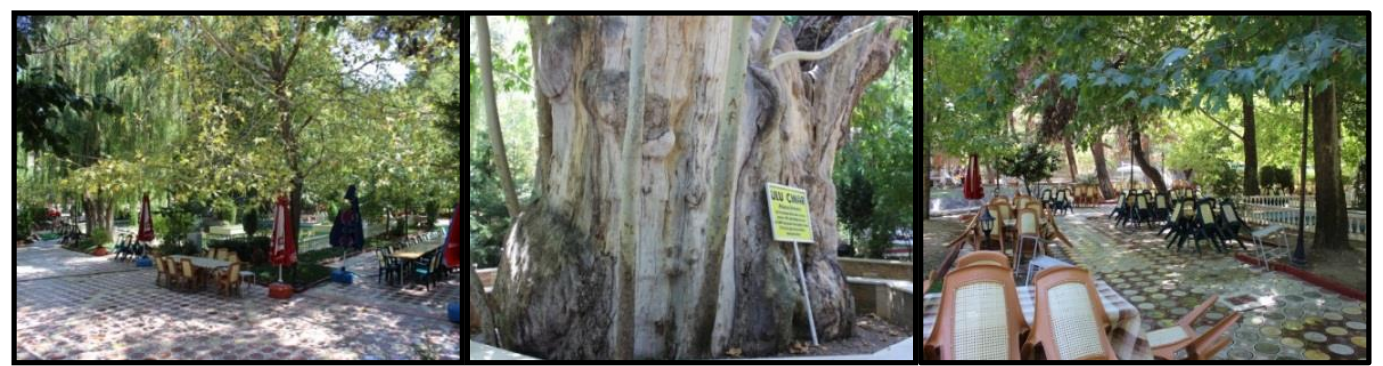

Şekil 15. Yeșil Yenice Kasabası piknik alanından görünümler (Kurt 2013)

\section{Ziyaret (Gölbaşı) kasabası piknik alanı}

Amasya-Taşova karayolunun 3. km.'sinden sola ayrılarak ulaşıımaktadır (Şekil 22). Alanın girişinde süs havuzu, yeşil alanlar, yeme-içme alanları ile piknik alanı bulunmaktadır (Şekil 16/a) (URL-2 2016, URL-4 2013). Bu alanın yukarı kısmında gölet, yeme-içme alanları, yeşil alanlar ve otopark yer almaktadır (Şekil 16/b). Sulama amaçlı
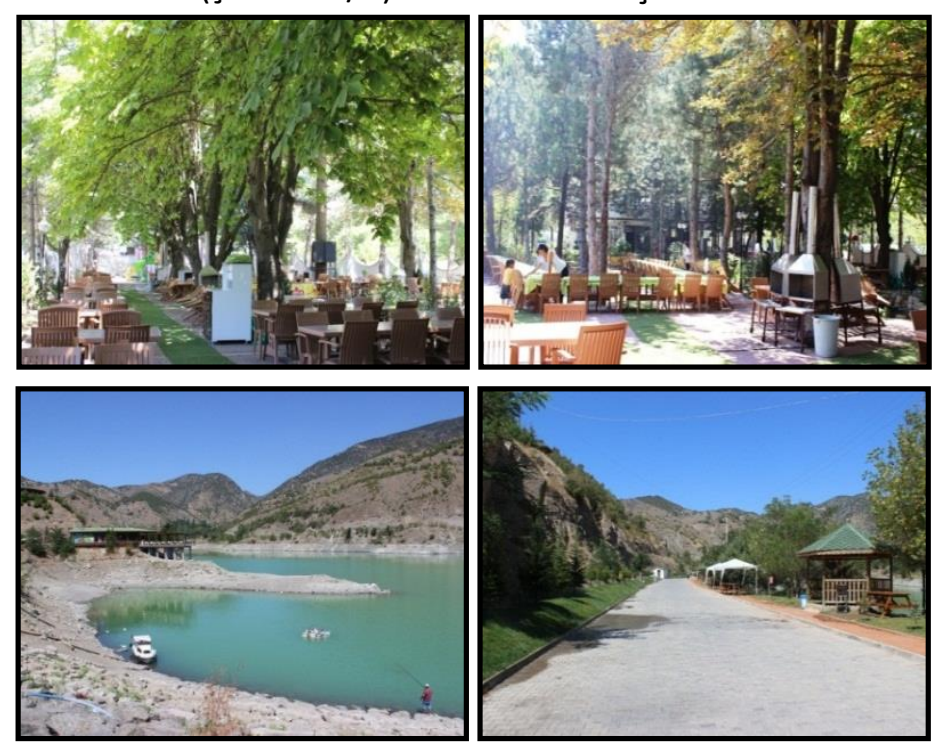

yapılan göletin çevresinde doğa yürüyüşü, olta balıkçılı̆̆ı, manzara seyri ve piknik yapma imkânı bulunmaktadır (URL-6 2016). Kent merkezine $3 \mathrm{~km}$. uzaklıktadır. Alan genel olarak yürüyüş, oturma, dinlenme, yeme-içme, sohbet etme, manzara seyretme, piknik yapma, fotoğraf çekme, balık tutma etkinliklerine olanak sağlamaktadır.

Şekil 16. (a-b) Ziyaret (Gölbaşı) Kasabası piknik alanından görünümler (Kurt 2013)

\section{Uygur Çamlıgöl piknik alanı}

Amasya-Tokat karayolunun 35 . km.'sinde Uygur Beldesinde yer almakta olup $2000 \mathrm{~m}^{2}$ yeşil alan içerisindedir. Alan içerisinde yeme-içme alanı, süs havuzu, bulunmaktadır (URL-4 2013, URL-5 2016). Kent merkezine $35 \mathrm{~km}$. uzaklıktadır. Alan oturma, dinlenme, yeme-içme, sohbet etme, yürüyüş, oyun oynama, piknik yapma etkinliklerine elverişlidir (Şekil 17, Şekil 22). çocuk oyun alanı, dinlenme alanı ve otopark

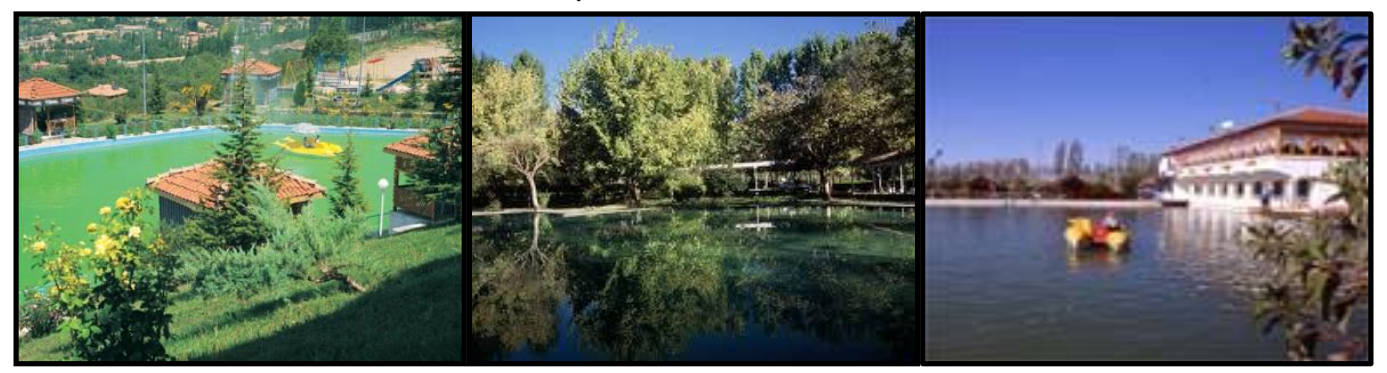

Şekil 17. Uygur Çamlıgöl piknik alanından görünümler (URL-7 2013) 
Ser Çoban piknik alanı

Alan kent merkezine $5 \mathrm{~km}$. uzaklıkta yer almakta olup daha çok adak kurbanı kesme ve mesire yeri olarak kullanılmaktadır. Alanda oturma, yeme-içme, piknik yapma, dinlenme etkinlikleri yapılmaktadır (Şekil 18, Şekil 22).

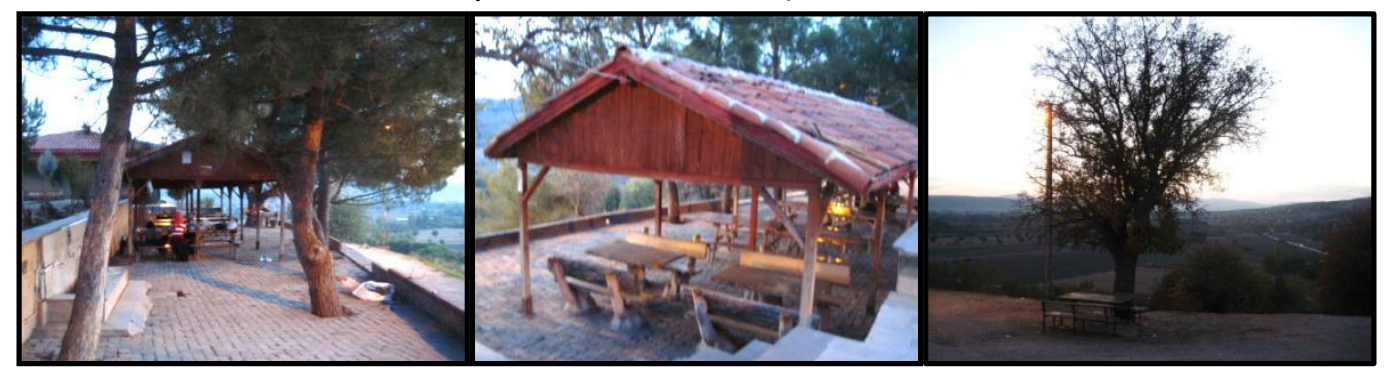

Şekil 18. Ser Çoban piknik alanından görünümler (Kurt 2013)

\section{Yassıçal Yaylagöl piknik alanı}

Amasya-Taşova karayolunun 7. km.'sinden sağa ayrılarak ulaşılmaktadır. Piknik alanı, kent merkezinden $16 \mathrm{~km}$. mesafede yer almaktadır. Alanda; havuz, dinlenme alanları, yapay şelale, çocuk oyun alanı, piknik alanı, spor alanı, otopark ve kamp alanı bulunmaktadır (URL-8 2013, URL-5 2016). Alan oturma, dinlenme, yeme-içme, sohbet etme, piknik yapma, yürüyüş, spor yapma, kamp yapma, manzara seyretme, fotoğraf çekme etkinliklerine imkân tanımaktadır (Şekil 19, Şekil 22).

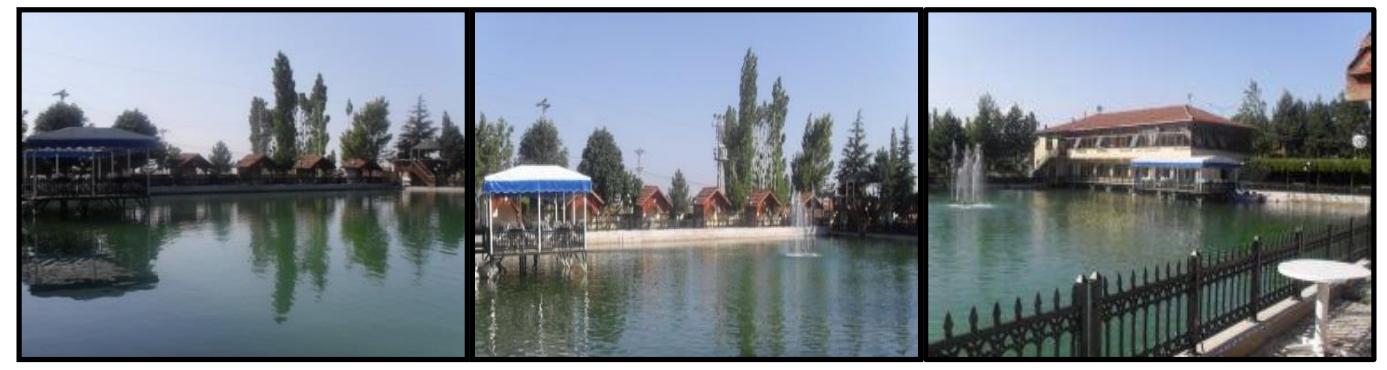

Şekil 19. Yassıçal Yaylagöl piknik alanından görünümler (URL-9 2013)

\section{Yedikır Barajı}

Yedikır Barajı sulama amacıyla inşa edilmiş bir baraj olup kent merkezine $32 \mathrm{~km}$. uzaklıkta yer almaktadır. Baraj gölü çevresinde yürüyüş parkuru, dinlenme alanı, yemeiçme alanı, piknik alanı ve balık üretim tesisleri yer almaktadır. Alan, 1. Derece doğal sit alanı olup su kuşları açısından önemli bir zenginliğe sahiptir (Ak ve ark. 2013, URL-6 2016). Alan yürüyüş, dinlenme, kuş gözlemciliği, doğa fotoğrafçılığı, balık tutma, gözlem yapma etkinlikleri için uygundur (Şekil 20, Şekil 22).

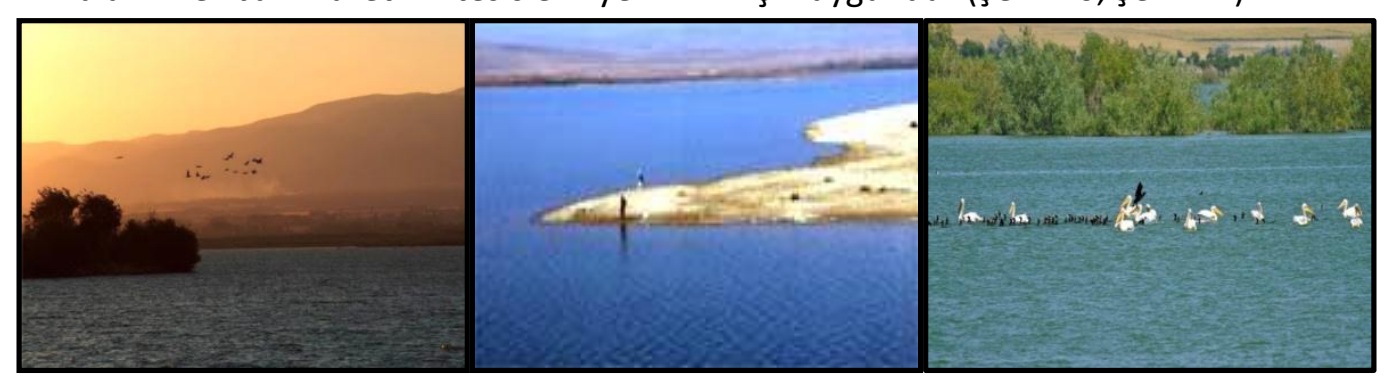

Şekil 20. Yedikır Barajı́ndan görünümler (URL-4 2013)

\section{Borabay Gölü}

1050 rakıma sahip Borabay Gölü, Amasya-Taşova karayolunun 44. km.'sinden sola ayrılan Taşova-Samsun karayolunu takiben $14 . \mathrm{km}$ 'den tekrar sola ayrilarak ulaşılmaktadır (URL-10 2016). Kent merkezine $55 \mathrm{~km}$. uzaklıktadır. illin sahip olduğu doğa harikası tek krater gölüdür. Bakanlar Kurulunca Turizm Merkezi olarak ilan edilmiştir. Ormanlık alan içerisinde kamp alanı, piknik alanları, yürüyüş parkuru ve dinlenme alanları bulunmaktadır. Sahip olduğu kaynak değerlerinden dolayı yerli ve yabancı turistler tarafından dikkat çekmektedir (URL-3 2013, URL-5 2016). 
Alanda doğa yürüyüşü, bisiklet sürme, kamp yapma, piknik yapma, doğa sporları yapma, motokros-jip safarifoto safari gezileri, doğa fotoğrafçılığı, gölde kayıkla gezinti etkinlikleri gerçekleştirilmektedir (Ak ve ark. 2013, URL-6 2016) (Şekil 21, Şekil 22).

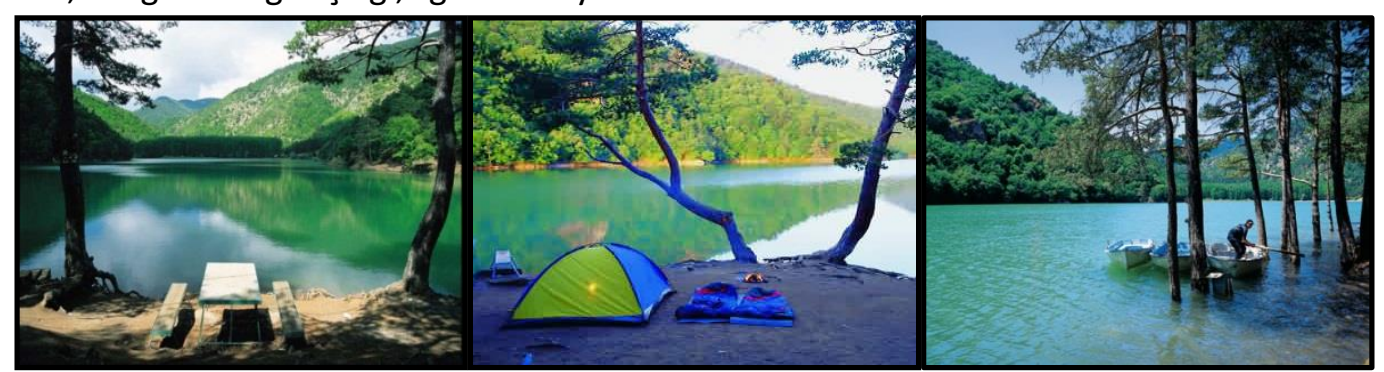

Şekil 21. Borabay Gölü’nden görünümler (URL-11 2013)

Şekil 14 ve Şekil 22'de belirtilen Amasya kent içi ve yakın çevresindeki rekreasyon alanlarından Macellan marka el tipi GPS kullanılarak alınan koordinatlar Arcview 10.1 programındaki sayısal haritalar ile uydu görüntüsüne işlenerek nihai harita oluşturulmuştur (Şekil 23). Bu alanlarda gerçekleştirilen etkinlikler özet olarak Çizelge 1 ve Çizelge 2 'de listelenmiştir.

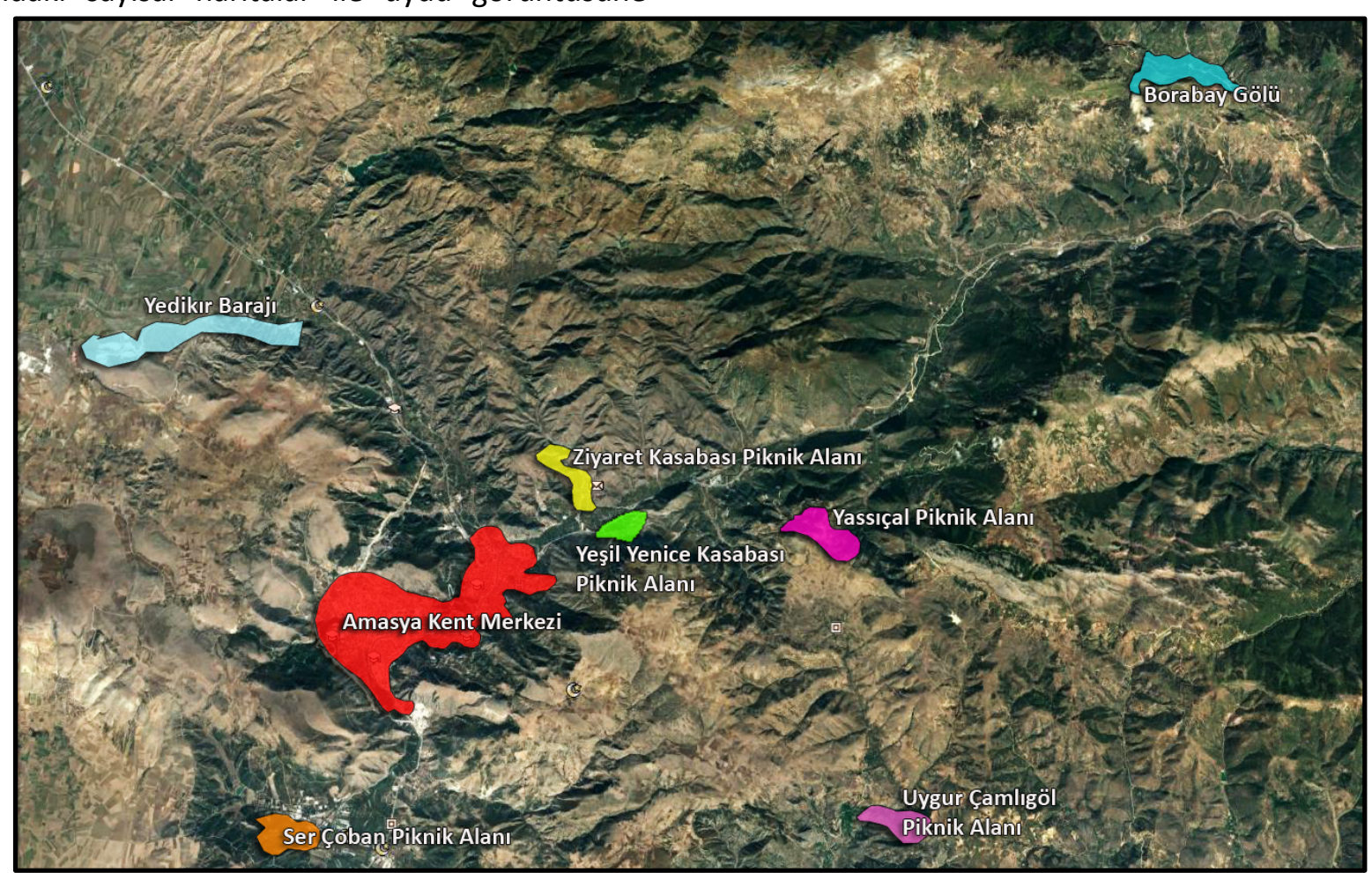

Şekil 22. Amasya kent çevresindeki rekreasyon alanlarının yerini gösteren harita 


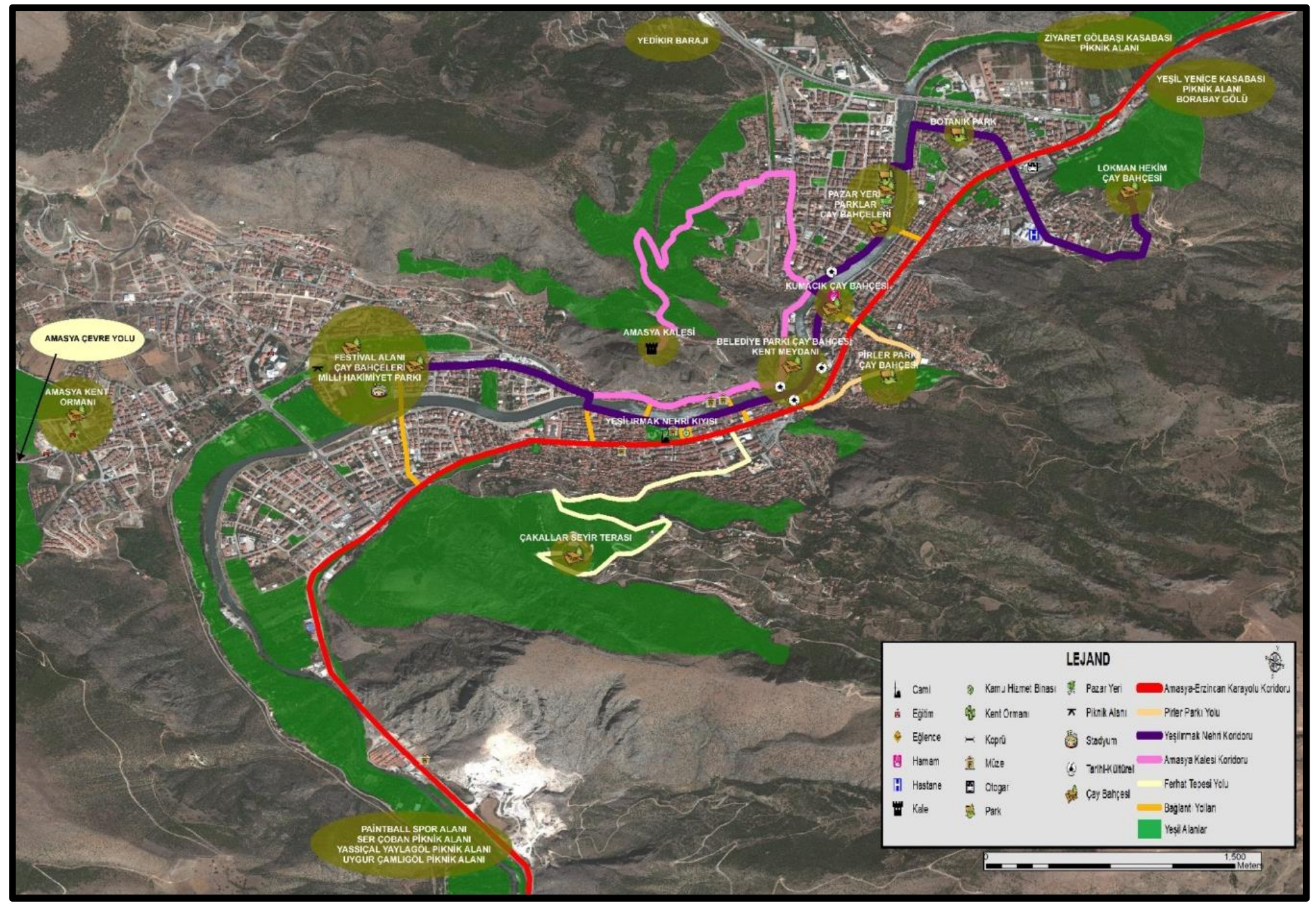

Şekil 23. Amasya kentindeki mevcut rekreasyon alanlarını gösteren harita (Kurt 2013) 
Çizelge 1. Amasya kent içindeki rekreasyon alanlarında gerçekleştirilen etkinlikler.

\begin{tabular}{|c|c|c|c|c|c|c|c|c|c|c|}
\hline Yapılan Etkinlikler & 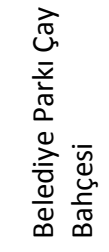 & 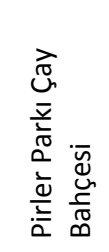 & 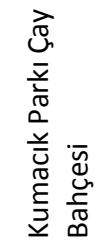 & 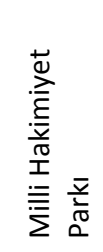 & 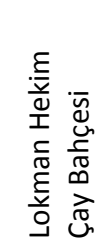 & 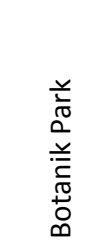 & 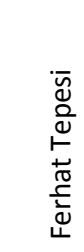 & 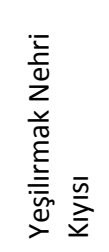 & 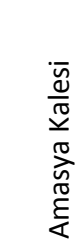 & 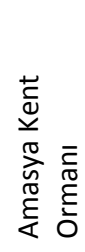 \\
\hline Yürüme & $x$ & $\mathrm{x}$ & $x$ & $x$ & $x$ & $\mathrm{x}$ & $\mathrm{x}$ & $x$ & $x$ & \\
\hline Dinlenme & $x$ & $x$ & $x$ & $x$ & $x$ & $x$ & $x$ & $x$ & $x$ & \\
\hline Manzara seyretme & $x$ & & & & $x$ & & $x$ & $x$ & $x$ & \\
\hline Fotoğraf çekme & $x$ & & & & $x$ & & $x$ & $x$ & $x$ & \\
\hline Gözlem yapma & & & & & & & & $x$ & & \\
\hline Bisiklet sürme & & & & & & & & $x$ & & \\
\hline Paten kayma & & & & & & & & $x$ & & \\
\hline Piknik yapma & & $x$ & & $x$ & & & & & & \\
\hline Yeme-içme & $x$ & $x$ & $x$ & $x$ & $x$ & $x$ & $x$ & $x$ & $x$ & \\
\hline Oyun oynama & $x$ & & & & & $x$ & & & & \\
\hline Spor yapma & & & & $x$ & & & & $x$ & & \\
\hline \multicolumn{11}{|l|}{ Bot turu } \\
\hline \multicolumn{11}{|l|}{ Kayıkla gezinti } \\
\hline Müzik dinletisi & $x$ & & & & & & & $x$ & & \\
\hline \multicolumn{11}{|l|}{ Kamp yapma } \\
\hline Balık tutma & & & & & & & & $x$ & & \\
\hline Kuş gözlemciliği & & & & & & & & & & \\
\hline Doğa yürüyüşü & & & & & & & & & & \\
\hline
\end{tabular}

Çizelge 2 Amasya kent çevresindeki rekreasyon alanlarında gerçekleştirilen etkinlikler

\begin{tabular}{|c|c|c|c|c|c|c|c|}
\hline Yapılan Etkinlikler & 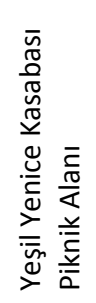 & 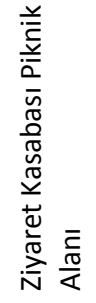 & 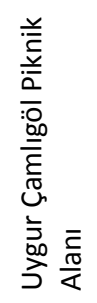 & 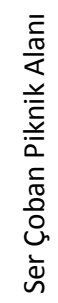 & 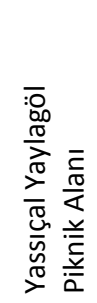 & 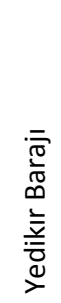 & 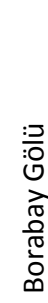 \\
\hline Yürüme & $\mathrm{x}$ & $x$ & $x$ & $x$ & $x$ & $x$ & $x$ \\
\hline Dinlenme & $x$ & $\mathrm{x}$ & $\mathrm{x}$ & $x$ & $x$ & $x$ & $x$ \\
\hline Manzara seyretme & $x$ & & & & & $x$ & $x$ \\
\hline Fotoğraf çekme & & $x$ & & & & $x$ & $x$ \\
\hline Gözlem yapma & & $x$ & & & & $x$ & $x$ \\
\hline Bisiklet sürme & & & & & & & $x$ \\
\hline \multicolumn{8}{|l|}{ Paten kayma } \\
\hline Piknik yapma & $x$ & $x$ & & $x$ & $x$ & $x$ & $\mathrm{x}$ \\
\hline Yeme-içme & $x$ & $x$ & $x$ & & $x$ & & $x$ \\
\hline Oyun oynama & & & & & $x$ & & \\
\hline Spor yapma & & $x$ & & & $x$ & & $x$ \\
\hline \multicolumn{8}{|l|}{ Bot turu } \\
\hline Kayıkla gezinti & & & & & & & $x$ \\
\hline \multicolumn{8}{|l|}{ Müzik dinletisi } \\
\hline Kamp yapma & & & & & $x$ & & $x$ \\
\hline Balık tutma & & $x$ & & & & $x$ & \\
\hline Kuş gözlemciliği & & & & & & $x$ & \\
\hline Doğa yürüyüşü & & & & & & $x$ & $x$ \\
\hline
\end{tabular}

\section{TARTIŞMA ve SONUÇ}

Bu çalışmada, Kurt (2013) ile Kurdoğlu ve ark. (2014)'ün Amasya kent içi ve çevresi için yerel halk tarafından tercih edilen rekreasyon alanları belirlenerek bu alanlarda gerçekleştirilen etkinlikler, alanların konumları ve kent merkezine olan uzaklıkları, bu alanlara nasıl ulaşılması gerektiği tespit edilmiştir. Rekreasyon alanlara ait 
öznitelik verileri katmanlar dâhilinde CBS ortamı ve Arcview 10.1 programındaki sayısal haritalar ile uydu görüntüsüne aktarılmıştır. Bu bağlamda; Cömert ve Bostancı (1999), Kafarov ve Çabuk (2002), Topay ve ark. (2003), Ölgen (2004), Çelik (2005), Esen (2005), Tecim (2008), Çuhadar (2010), Kurdoğlu ve ark. (2012), Njegus (2013), Çelik (2015), Kurdoğlu ve ark. (2016) nın farklı alanda gerçekleştirmiş olduğu CBS tabanlı kent bilgi sistemi, turist bilgi sistemi, turizm kaynakları bilgi sistemi, kampüs bilgi sistemi, donatı bilgi sistemi çalışmaları incelenerek Amasya kenti için rekreasyon alanları bilgi sistemi veri tabanı oluşturulmuştur. Elde edilen veriler ışığında CBS ortamında son haline getirilmiştir.

Kentlerde rekreasyon alanlarının bilinmesi kent halkı ve kente ziyarete gelen turistler açısından önemlidir. Çalışma kapsamında oluşturulan rekreasyon alanları bilgi sistemi sayesinde kent halkı, kente gelen yerli-yabancı turistler yapmak istedikleri etkinliklere göre rekreasyon alanlarını sorgulayarak gidecekleri rekreasyon alanına kolaylıkla karar verebilme imkanına sahiptir. Ayrıca bu sistem kent için yapılan ve yapılacak olan diğer bilgi sistemlerine (kent bilgi sistemi, ulaşım bilgi sistemi, turizm bilgi sistemi) de entegre edilebilmesi, kenti tanımak için rehber niteliğinde olması, yaşam kalitesini arttırması, kente ekonomik katkı sağlaması açısından da önemlidir.

Çalışmanın sonuçlarına göre; Amasya kent içindeki rekreasyon alanları genel olarak yürüme, dinlenme, oturma, manzara seyretme, yeme-içme, fotoğraf çekme etkinliklerine olanak sağlamaktadır. Bu alanlar içerisinde en fazla etkinlik potansiyeline sahip olan Yeşilırmak Nehri Kıyısının ise bu durumu yeteri kadar değerlendiremediği, bu alanda etkinlik sayısının sınırlı olduğu görülmektedir. Kent çevresindeki rekreasyon alanları yürüme, dinlenme, oturma, manzara seyretme, yeme-içme, fotoğraf çekme, piknik yapma etkinlikleri gerçekleştirilmektedir. Kent çevresindeki alanlar içerisinde Borabay Gölü farklı etkinliklerin gerçekleşmesine olanak sağlamaktadır. Kent içi ve çevresindeki mevcut rekreasyon alanlarının ise yeterli olmadığı ve etkinlik çeşitliliğinin az olduğu görülmektedir.

Kentte gerçekleştirilen etkinlik çeşitliliğinin arttırılmasının kent imajına olumlu yönde katkı sağlayacağı düşünülmektedir. Ayrıca oluşturulan rekreasyon alanları bilgi sistemi, bu çalışmada belirlenen alanlar dışında kalan ya da kullanıma yeni açılan alanların (parklar, çay bahçesi, piknik alanı,...) da öznitelik verilerinin veri tabanına işlenmesi ve değişikliklerin sisteme anlık girilmesine, bu sayede veri tabanının güncel kalabilmesine olanak tanıyacaktır.

\section{TEŞEKKÜR}

Bu çalışma; 1130143 no'lu TÜBiTAK ÇAYDAG projesi kapsamında bir bölüm olan, KTÜ Fen Bilimleri Enstitüsü Peyzaj Mimarlığı ABD’nda hazırlanmış ‘Amasya Kenti İçin Yeşilırmak Koridorunu İçine Alan Bir Kentsel Yeşilyol Önerisi' adlı Yüksek Lisans Tezi'nden yararlanılarak oluşturulmuştur. Desteğinden dolayı TÜBiTAK kurumuna teşekkürlerimizi sunarı.

\section{KAYNAKLAR}

Ak U, Karaman E, Kartal K (2013) Amasya ilinde doğa turizmi master planı 2013-2023. T.C. Orman ve Su İşleri Bakanlığı, Doğa Koruma ve Milli Parklar, XI. Bölge Müdürlüğü, Amasya Şube Müdürlüğü, Amasya.

Akten M (2003) Isparta ilindeki bazı rekreasyon alanlarının mevcut potansiyellerinin belirlenmesi. Süleyman Demirel Üniversitesi Orman Fakültesi Dergisi, 2:115-132.

Akten $M$ ve Akten S (2011) Rekreasyon potansiyellerinin belirlenmesine yönelik bir model yaklaşımı: gülez yöntemi. I. Ulusal Sarıgöl İlçesi ve Değerlendirme Sempozyumu, Sarıgöl.

Akyüz H, Kul M ve Yaşartürk F (2014) Rekreasyon açısından ormanlar ve çevre. International Journal of Science Culture and Sport, 1:881890.

Albay N (2006) Üsküdar-haydarpaşa arası kıyı düzenlemesinin rekreasyonel açıdan değerlendirilmesi. Yüksek Lisans Tezi, Bahçeşehir Üniversitesi Fen Bilimleri Enstitüsü Çevre Tasarımı Yüksek Lisans Programı, İstanbul.

Anonim (2010) Amasya belediyesi stratejik planı 2010-2014. Amasya.

Aranoff S (1989) Geographical information systems: a management perspective. WDL Publications, Ottawa, Canada.

Cömert Ç, Bostancı H (1999) Turist bilgi sistemleri ve Trabzon örneği. Yerel Yöntemlerde Kent Bilgi Sistemi Uygulamaları Sempozyumu, Bildiriler Kitabı, 168-181, Trabzon.

Çelik K (2005) Turizm kaynakları bilgi sistemi (TKBS) oluşturulması: Gümüşhane örneği. TMMOB Harita ve Kadastro Mühendisleri Odası 10. Türkiye Harita Bilimsel ve Teknik Kurultayı, Ankara.

Çelik K T (2015) CBS tabanlı bir yerleşke donatı bilgi sisteminin (YEDBis) oluşturulması: Karadeniz Teknik Üniversitesi kanuni yerleşkesi örneği. Karadeniz Teknik Üniversitesi Fen Bilimleri Enstitüsü Peyzaj Mimarlığı Anabilim Dalı, Yüksek Lisans Tezi, Trabzon. 
Çuhadar M (2010) Burdur ili turizm değerlerini tanıtmada bilgi sistemlerinin önemi ve bir model önerisi. Geçmişten Geleceğe Burdur Halk Kültürü ve Turizm Sempozyumu, Burdur.

Esen Ö (2005) Turizm bilgi sistemleri için tarihi ve kültürel envanterin çıkarılması ve Manavgat örneği. Selçuk Üniversitesi Fen Bilimleri Enstitüsü Yüksek Lisans Tezi, Konya.

Google Earth (2013) 2009-2010-2011-2012 uydu görüntüleri.

Gökalp D D ve Yazgan M E (2013) Kırsal peyzaj planlamada agroturizm ve agriturizm. KMÜ Sosyal ve Ekonomik Araştırmalar Dergisi, 15(24):25-29.

Gül A, Çatal Y, Çoban H O, Polat E, Gülcü S, Yılmaztürk A, Topay M, Örücü Ö K, Tuğluer M, Türker B, Kavak I, Keleş E, Uzun Ö F ve Uysal S (2015) Kent ağaçları bilgi sistemi modeli, 1001 TÜBіTAK Projesi, http://kabsis.sdu.edu.tr.

Ilhan i (1999) Bölgesel turizm planlaması modeli ve nevşehir örneği. Dokuz Eylül Üniversitesi Sosyal Bilimler Enstitüsü Turizm İşletmeciliği Anabilim Dalı, Doktora Tezi, İzmir.

Kafarov R, Çabuk A (2002) CBS ve multimedya destekli internet tabanlı turizm bilgi sistemi oluşturulması: Belek örneği, TÜBіTAK TURISKOTEK Projesi Sonuç Raporu.

Karadeniz N (1995) Sultan sazlığı örneğinde, ıslak alanların çevre koruma açısından önemi üzerine bir araştırma, Ankara Üniversitesi Fen Bilimleri Enstitüsü, Doktora Tezi, Ankara.

Karaküçük S (1999) Rekreasyon (boş zamanları değerlendirme). 3. Baskı, Ankara.

Karahan F ve Orhan T (2009) Çoruh havzası uzundere vadisinin kırsal rekreasyon planlaması yönünden suya dayalı olanakları. Kırsal Çevre Yıllığı, pp. 54-81.

Kurdoğlu B Ç, Demirel Ö, Nişancı R, Özdemir B, Bayramoğlu E, Erbaş Y $S$ (2012) Karadeniz teknik üniversitesi yerleşkesi örneğinde üniversite doğal ve yapay peyzaj materyalleri bilgi sistemi modeli oluşturulması üzerine bir araştırma, BAP Arastırma Projesi, Sonuç Raporu.

Kurdoğlu B Ç, Özdemir I, Bayramoğlu E (2013) Doğal-yapay peyzaj materyalleri ve kullanıc ilişkisi: KTÜ kanuni yerleşkesi örneği. Kastamonu Üniversitesi Orman Fakültesi Dergisi, 13 (1):164-174.

Kurdoğlu B Ç, Erbaş Y S, Demirel Ö, Nişanci R ve Çelik K T (2015) An investigation on creating university landscape materials information system model: karadeniz technical university case study, in: Environment and Ecology at the Beginning of 21. Century, Efe R, Bizzarri C, Cürebal i, Nyusupova G N, Eds, ST.Klıment Ohrıdski Unıversıty Press Sofia, Sofia, 456-471.

Kurdoğlu B Ç, Demirel Ö, Kalın A, Kurt S S, Usta Z, Çelik K T (2014) Amasya kenti için Yeşilırmak koridorunu içine alan bir kentsel yeşilyol modeli oluşturmak, TÜBITAK 1002 Projesi, Sonuç Raporu.

Kurdoğlu B Ç, Çelik K T, Kurt Konakoğlu S S, Erbaş Y S (2016) The relationship among user, activity and space of street furniture placed at kanuni campüs - Karadeniz Technical University. 3rd International GeoAdvances Workshop 'ISPRS Workshop on Multi- dimensional \& Multi-scale Spatial Data Modeling', 19-23, İstanbul, Turkey,

Kurdoğlu B Ç ve Kurt S S (2017) Determination of greenway routes using network analysis in Amasya, Turkey. Journal of Urban Planning and Development, 143 (1): 05016013-1-05016013-7.

Kurt S S (2013) Amasya kenti için yeşilırmak koridorunu içine alan bir kentsel yeşilyol önerisi. Karadeniz Teknik Üniversitesi Fen Bilimleri Enstitüsü Peyzaj Mimarlığı ABD, Yüksek Lisans Tezi, Trabzon.

Ölgen M K, İnceoğlu M M, Cinsdikici M, íkiz F (2004) Ege üniversitesi kampüs coğrafi bilgi sistemi, 3. coğrafi bilgi sistemleri bilişim günleri, İzmir.

Özalp T, Çelenk E ve Taştan H (1995) Uzaktan algılama ve CBS teknoloji entegrasyonu ve geniş ölçekte kullanım alanları. Türkiye Ulusal Jeodezi-Jeofizik Birliği Genel Kurulu, Bildiriler Kitabı, Harita Genel Komutanlığı, Ankara.

Njegus A (2013) http://www.slideshare.net/AngelinaNjegus/lesson-2ebusiness-in-tourism.

Sağlam A, Duzgun H S B ve Usul N (2004) Çanakkale savaşlarına farklı bir yaklaşım: coğrafi bilgi sistemlerinde gelibolu 1915. Çanakkale Araştırmaları Türk Yıllığı - The Turkish Yearbook of Gallipoli Studies, Çanakkale Onsekiz Mart Üniversitesi Atatürk ve Çanakkale Savaşlari Araştırma Merkezi, Çanakkale, 2:117-133.

Tecim V (2008) Coğrafi bilgi sistemleri harita tabanlı bilgi yönetimi. Dokuz Eylül Üniversitesi Fen Bilimleri Enstitüsü, İzmir.

Topay M, Kaya L G, Yıldırım B, İkiz E, Demirtaş S Ö (2003) ZKÜ bartın yerleşkesi kampüs bilgi sistemi. ZKÜ Bartın Orman Fakültesi Dergisi, Bartın, 5 (5):71-77.

URL-1 (2016) http://www.choruh.com/tr, 2 Haziran 2016.

URL-2 (2016) amasya.gov.tr, 2 Haziran 2016.

URL-3 (2016) encyclopine.org, 1 Haziran 2016.

URL-4 (2013) http://www.amasya.web.tr/turizm.html, 13 Ekim 2013.

URL-5 (2016) www.amasyakultur.gov.tr, 6 Haziran 2016.

URL-6 (2016) bolge11.ormansu.gov.tr, 2 Haziran 2016.

URL-7 (2013)

http://www.karadenizgezi.net/Amasya_Dogal_Guzellikleri.htm, 30 Ekim 2013.

URL-8 (2013) http://www.greenways.org/, 25 Kasım 2013.

URL-9 (2013)

http://www.yassical.bel.tr/index.php?option=com_content\&view $=$ article\&id=71\&ltemid=80, 30 Ekim 2013.

URL-10 (2016) www.bigglook.net, 3 Haziran 2016.

URL-11 (2013)

http://www.amasyakulturturizm.gov.tr/TR,59552/borabaygolu.html, 30 Ekim 2013.

Yılmaz R (2006) Saros körfezinin turizm ve rekreasyonel kullanım potansiyeli üzerine bir araştırma. Süleyman Demirel Üniversitesi Orman Fakültesi Dergisi, 1:67-82.

Yomralığlu T (2002) Coğrafi bilgi sistemleri, 2. Basım, Trabzon. 